\title{
NEW TECHNIQUES FOR PRETREATMENT, DYEING AND FINISHING OF SOME EGYPTIAN COTTON FABRICS IN ONE- BATH
}

\author{
SALEH, M. S. ${ }^{1}$ AND A. N. AZIZ ${ }^{2}$ \\ 1. Cotton Research Institute ,ARC, Giza \\ 2. Textile Division, National Research Center, Dokki, Giza, Egypt
}

(Manuscript received 24 June 2009)

\begin{abstract}
The present study was taken up as an exploratory study to test the possibility of using one-bath scouring, dyeing and finishing (OSBDF) by the exhaustion and pad-dry techniques as an economical treatment process of fabrics made from two Egyptian cotton varieties namely Giza 89 and Giza 80 . Detailed laboratory experiments were performed to investigate the feasibility of this process. The treated and untreated fabric samples were tested for their mechanical properties expressed as tensile strength ( $\mathrm{g} / \mathrm{tex}$ ) and elongation \%. Dyeing performance in terms of color parameters $(\mathrm{K} / \mathrm{S}, \Delta \mathrm{E})$, and fastness properties (wash, perspiration, and crocking) were also studied.

The results of this investigation showed that, The K/S value of the treated fabrics by the conventional method is slightly better than the cotton fabrics treated by the one-bath method. The K/S value of the treated fabrics increased with the increase in concentration of $\mathrm{NaOH}$ and $\mathrm{Na}_{2} \mathrm{SO}_{4}$, addition of finishing agent and pretreatment time. The tensile strength, elongation, and color difference of the treated fabrics by this method are of the acceptable limit. The addition of soluble chicken feather as a finishing agent $(2 \mathrm{~g} / \mathrm{l})$ increase the $\mathrm{K} / \mathrm{S}$ value and maintain the tensile strength, and elongation from degradation. The wash, perspiration, and crocking dye fastness properties of the cotton fabrics are of the acceptable standards

Keywords: Egyptian cotton, conventional method, one-bath method, finishing agent.
\end{abstract}

\section{INTRODUCTION}

Textile wet processing is one of the most polluting industrial processes. It is a complex process. The same result can be achieved by applying some different technologies and with the use of some different kinds of chemical materials and machines. The complexity of the process also depends on the composition of textile material, (Gailutè et al. 2004).

The concept of one-bath dyeing and finishing (ODF) is to combine the two steps of dyeing and finishing. The ODF process has been studied using cotton fabrics dyed with reactive and direct dyes. The advantages of the ODF process are reduced energy, water consumption and time of operation, (Siriwan. 2006). 
Conversion of raw cotton fabrics to dyeing fabrics by conventional process involves four distinct steps namely, desizing to reduce the size, scouring to remove fats, waxes and pectins, bleaching to remove coloring maters and dyeing. During these various steps the overall energy, water consumption and follow up wastewater processing will be quite high.

Gailutè et al. (2004) reported that reducing pollution in wet processing of cotton/polyester fabrics by using new technologies should be evaluated not only from the economical point of view but also from the environmental impact which can be assessed by comparison of environmental performance indicators: water and energy consumption, and consumption and emissions of chemical materials.

Over the last fifteen years, energy conservation was emphasized and different approaches were made to reduce energy consumption. One of these approaches involves combination of certain steps together, thereby shortening the processing steps and consequently conserving energy. For instance, Hafiz et al. (1991) have studied the combined desizing, scouring, and bleaching of lommstate cotton fabric and loomstate cotton/polyester blended fabric using $\mathrm{NaCIO}_{2} / \mathrm{KMnO}_{4}$ or $\mathrm{NaClO}_{2} / \mathrm{H}_{2} \mathrm{O}_{2}$ oxidizing system.

Yen, and Huang, (1997) have focused primarily on one bath treatments for desizing, scouring and bleaching, rather than mercerization. This is primarily because the former treatments are conducted primarily at high temperatures. However, high temperatures are disadvantageous to mercerization. In a one-step desizing, scouring and belaching treatment the process is conducted in alkaline liquours, as indeed is mercerization. Thus, this study combined these four treatments by dipping the fabrics into highly alkaline sodium hydroxide solutions at various temperatures, and then curing the fabrics at high temperature. Consequently, the complete process could be shortened to save energy and thereby lower the cost. The results indicate the Feaibility of a one-step process for desizing, scouring, bleaching and mercerisating cotton fabrics.

Sekar, (1999) reported that it is possible to scour and bleach cotton fabric at $60^{\circ} \mathrm{C}$ with sodium chlorite in a single-stage based on an emulsified solvent scouring agent and a trichloroethanolamine hydrochloride activated sodium chlorite bleaching, agent. Min and Haung (1999) confirmed that the feasibility of one - step process for desizing, scouring, bleaching and mercerizing of cotton fabrics. Single stage bleaching process using hydrogen peroxide requires some additional chemicals that can act as activator, stabiliser, surfactant and scouring agents. Strongly alkaline solution of hydrogen peroxide has been advocated for such combined processes. Sodium persulphate and potassium persulphate boost the single stage operation in presence 
of hydrogen peroxide. Other compounds which accelerate the peroxide reactions are urea, methyl carbonate and tetraacetylethylenediamine.

Mortazavi, (2008) introduced potassium permanganate as an oxidizing agent for simultaneous desizing and bleaching of greige cotton fabric for the first time. The results have demonstrated that the fabric properties including the whiteness index of this method are comparable with those of the conventional hydrogen peroxide bleaching method. One of the major advantages of this method relative to the other methods is its potentiality for simultaneous desizing and bleaching of greige cotton fabric, which will save energy, water and time.

In the same approach to reduce energy and water consumption, Polonca and petra (2007) studied bioscouring and bleaching of cotton with pectinase enzyme and peracetic acid in one bath with the addition of a chelator. Tetrasodium pyrophosphate, which does not deactivate pectinases, has proved an efficient chelator. The analyses of a cotton fabric treated in a single bath with acidic and alkaline pectinases confirmed the efficiency of such treatment. A sufficient quantity of wax and pectin was removed and, because of that, the absorbance of the treated fabric was improved. The damage to the cotton fibres was negligible and the degree of whiteness obtained was uniform and adequate for further dyeing.

Subramanianeral. (2005) reported that enzyme treatment paves way for a new, unconventional technique of dyeing within the bleaching bath. from this new approach in the textile wet processing industry, it was possible to reduce the huge amount of water (by avoiding the extensive washing cycle after bleaching and dyeing in the catalase-treated bleached bath), considerable energy and time.

Huang and Yen, (1997) proposed that desizing, scouring bleaching and dyeing can be done in one bath and the aforesaid defects will be overcome.

This study is focused on the possibility of scouring, dyeing, and finishing of Egyptian Cotton Fabrics in One-Bath using Reactive Dyes

\section{MATERIALS AND METHODS}

\section{A. Fabric}

Untreated cotton fabrics of Egyptian cotton varieties namely Giza 89, and Giza 80 were purchased from Misr- El- Mehala for Spinning and Weaving Company.

The Specific properties of raw cotton fabrics for both Giza 80, and Giza 89 respectively are: Plain weave 1/1, Weight of square meter: $190.8 \mathrm{~g}$. Number of threads per $\mathrm{cm}$ of warp: 26 , Number of threads per $\mathrm{cm}$ of weft: 26 , Count number of yarn : 20 and Plain weave 1/1, Weight of square meter: $130.8 \mathrm{~g}$. Number of threads 
per cm of warp: 44, Number of threads per cm of weft: 32 and Count number of yarn : 40 .

\section{B. Chemical reagents}

Chemicals used in this study were sodium hydroxide, sodium sulfate, sodium carbonate (LR grade), Hydrogen peroxide (30\% LR grade) from Aldrich, acetic acid, sodium sulphate, mercerol as surfactant and soap. The dye used in this work was Remazole reactive R.R. finishing agent used was soluble chicken feather as described by Khaled et al (2006).

\section{Methods}

\section{A. Conventional method}

Scouring, bleaching and dyeing were carried out according to the procedure described by Huang (1999).

\section{B. One-Bath method}

Treatment was done with $\mathrm{NaOH}(2 \mathrm{~g} / \mathrm{l}-4 \mathrm{~g} / \mathrm{l}-6 \mathrm{~g} / \mathrm{l}, 8 \mathrm{~g} / \mathrm{l})$ and $0.2 \mathrm{~g} / \mathrm{l}$ surfactant, with bath ratio1:30 at $95^{\circ} \mathrm{C}$ and times (15- 30-45) minutes, the solutionremained from pretreatment was not thrown away. Acetic acid was used to neutralize it into weak alkaline, after which $1 \%$ of remazol reactive yellow R.R was added, followed by sodium sulfate as a catalyst $(10 \mathrm{~g} / \mathrm{l}-20 \mathrm{~g} / \mathrm{l}-30 \mathrm{~g} / \mathrm{l})$ and sodium carbonate $15 \mathrm{~g} / \mathrm{l}$, then a known concentration ( $0.5 \%-3.0 \%$ ) of the soluble chicken feather was added as a finishing. The dyed samples removed from dyeing bath and rinsed in water at $25^{\circ} \mathrm{C}$ and then air-dried as shown in the curve below.

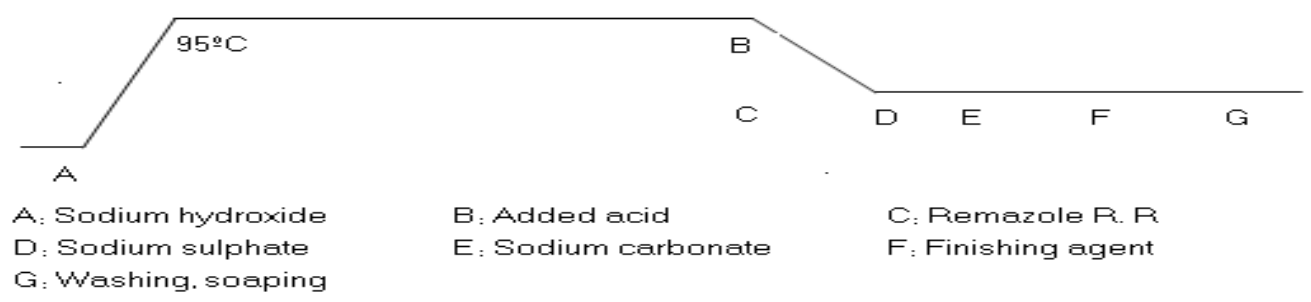

\section{Measurements and Analysis:}

\section{Evaluation of the properties of the treated fabrics}

The color strength $(\mathrm{K} / \mathrm{S})$ of the treated samples was determined using Perkin Elmer Spectrophotometer, Model Lambda 35 equipped with integrated sphere according to Kubelka-Munk equation:

$$
K / S=\left[(1-R)^{2} / 2 R\right]
$$


Color difference $(\Delta \mathrm{E})$ was measured by using the Win lab software CIE CMC (1995).

Tensile strength (g/tex) and elongation (\%) were measured according to ASTM D412-98a using Zwick testing machine of model Z010 and equipped with 10Kn load cell and the testing was conducted at speed of $100 \mathrm{~mm} / \mathrm{min}$. The results obtained were based on an average of ten tests in the wrap direction of each sample.

\section{Fastness properties:}

(a) Washing fastness (WF), was done according to ISO 105-C01:1998(E). Two single fiber adjacent fabrics complying with the relevant sections of F01 to F08 of ISO 105-F: 1989.

(b) Synthetic perspiration fastness (PF) was measured according to ISO-E04: 1994.

(c) Crocking fastness both dry and wet examined according AATCC method-81989.

\section{RESULTS AND DISCUSSION}

\section{Effect of $\mathrm{NaOH}$ concentration on color strength (K/S):}

The results shown in figs. 1 and 2, revealed that the $\mathrm{K} / \mathrm{S}$ value of treated fabrics increased with increasing $\mathrm{NaOH}$ concentration due to more removal of starch and impurities from the test fabric, allowing the dye to infiltrate the fabric more easily until it reach $6 \%$. The dyebility of the fabric samples decreased with increased $\mathrm{NaOH}$ concentration more than $8 \%$, due to the formation of the oxycellulose, that cause degradation of the fiber.

It is clear that in one-step methods, fabrics had lower color strength than the conventional method. This is plausibe because during the one-bath treatment, the solution used in the treatment contained pretreatment chemicals and post-treatment residual impurities, and with the effectiveness of the reactive dye itself, some form of reaction would have occurred, resulting in the reduction of the color strength of the fabrics. 


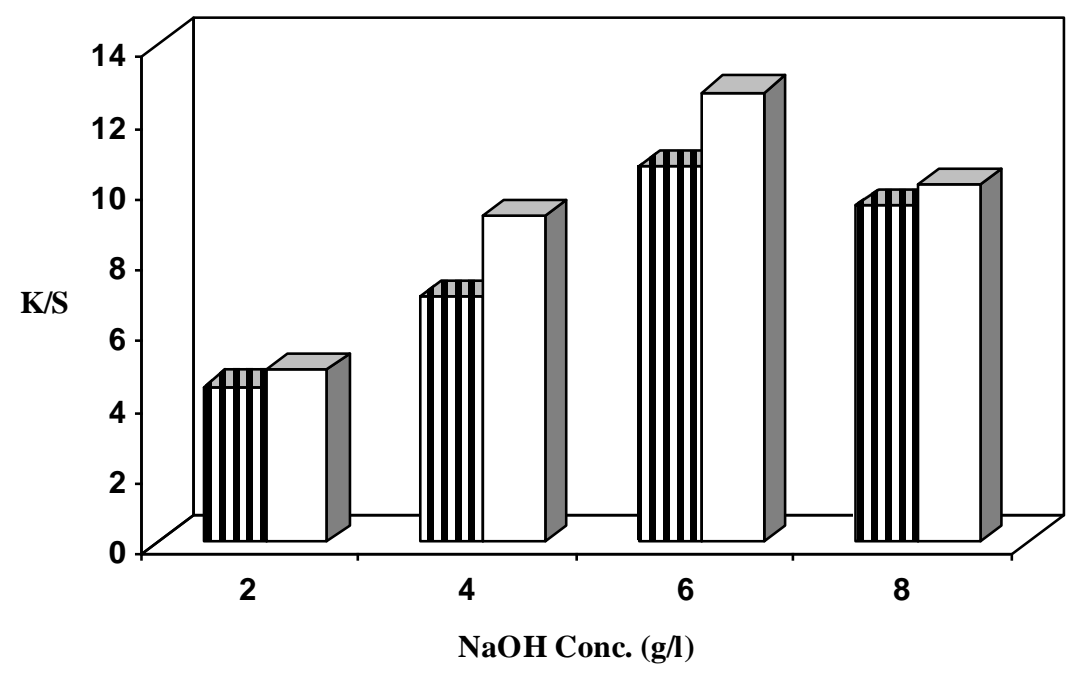

Figure 1. Effect of $\mathrm{NAOH}$ concentration on the color strength of Giza 89 cotton fabric.

(I: conventional processes, II: one- bath process time: 30 minutes $\mathrm{Na}_{2} \mathrm{SO}_{4}$ concentration: $(30 \mathrm{~g} / \mathrm{l})$, finishing agent: none).

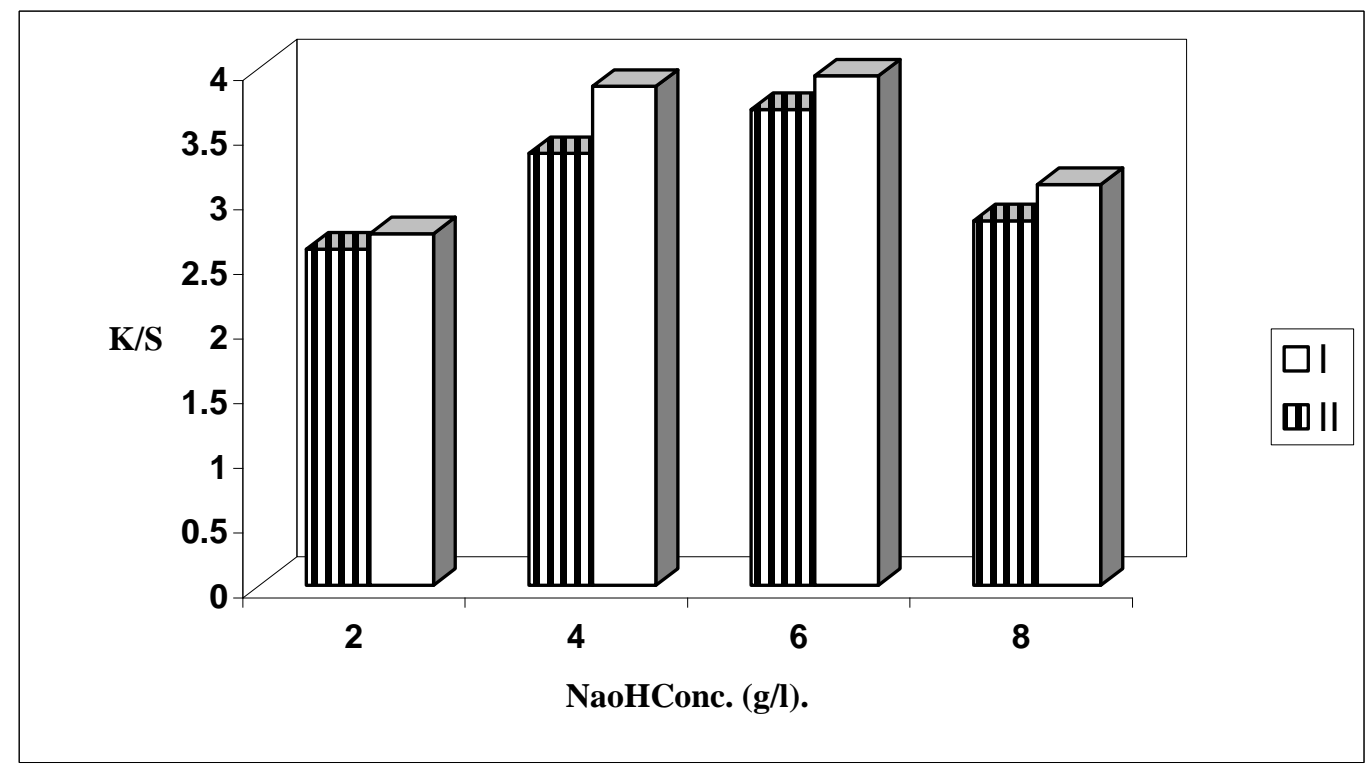

Figure 2. Effect of $\mathrm{NAOH}$ concentration on the color strength of Giza 80 cotton fabric (I: conventional processes, II: one- bath processes time: 30 minutes $\mathrm{Na}_{2} \mathrm{SO}_{4}$ concentration: $(30 \mathrm{~g} / \mathrm{l})$, finishing agent: none). 
These results indicate that the color strength of Giza 89 was higher than that of Giza 80 due to its higher Fiber maturity forming more free hydroxyl groups by the addition of $\mathrm{NaOH}$ and thus leads to more dyeability.

\section{Effect of time on color strength (K/S)}

It is clear from figs. 3, and 4 that the K/S values of the treated samples increased according to the time from pretreatment until the treatment it reached 45 minutes. This is because with longer time taken for treatment, more impurities were eliminated and there were increasingly less opportunities for obstruction of dyeing infiltrating the fabrics. Since the time treatment effect of 45 , and 60 minutes were similar, it would be more economical to use 45 minutes as it would still achieve the purpose of eliminateing nearly all the fabric sample impurities (wax, undesired materials, etc...). The results showed that the color strength of Giza 89 was higher than that of Giza 80 due to its higher maturity that formed more free hydroxyl groups with longer time leading to more dyeability.

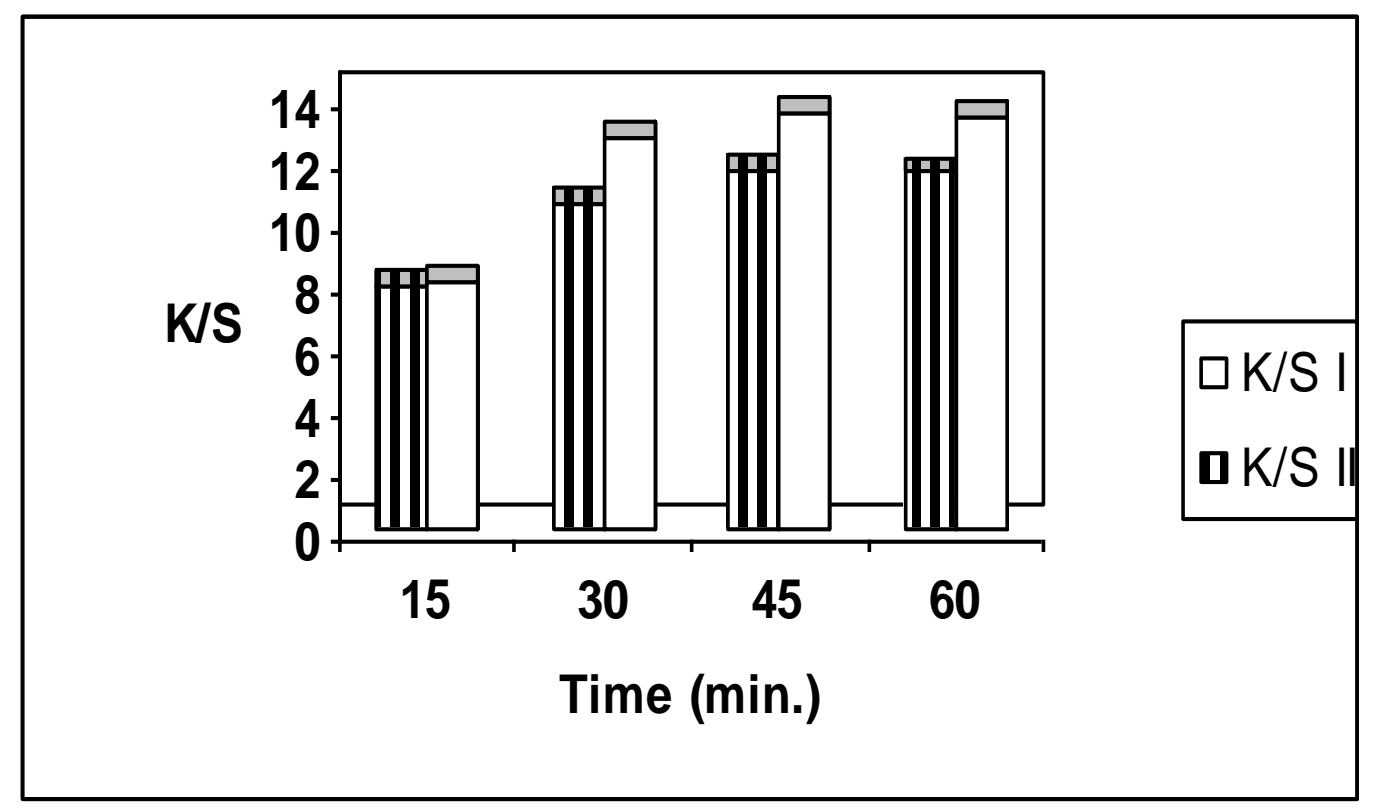

Figure 3. Effect of time on the color strength of Giza 89 cotton fabric (I: conventional processes, II: one- bath processes $\mathrm{NaOH}$ concentration: $(6 \mathrm{~g} / \mathrm{l})$ $\mathrm{Na}_{2} \mathrm{SO}_{4}$ concentration: $(30 \mathrm{~g} / \mathrm{l})$, finishing agent: none). 


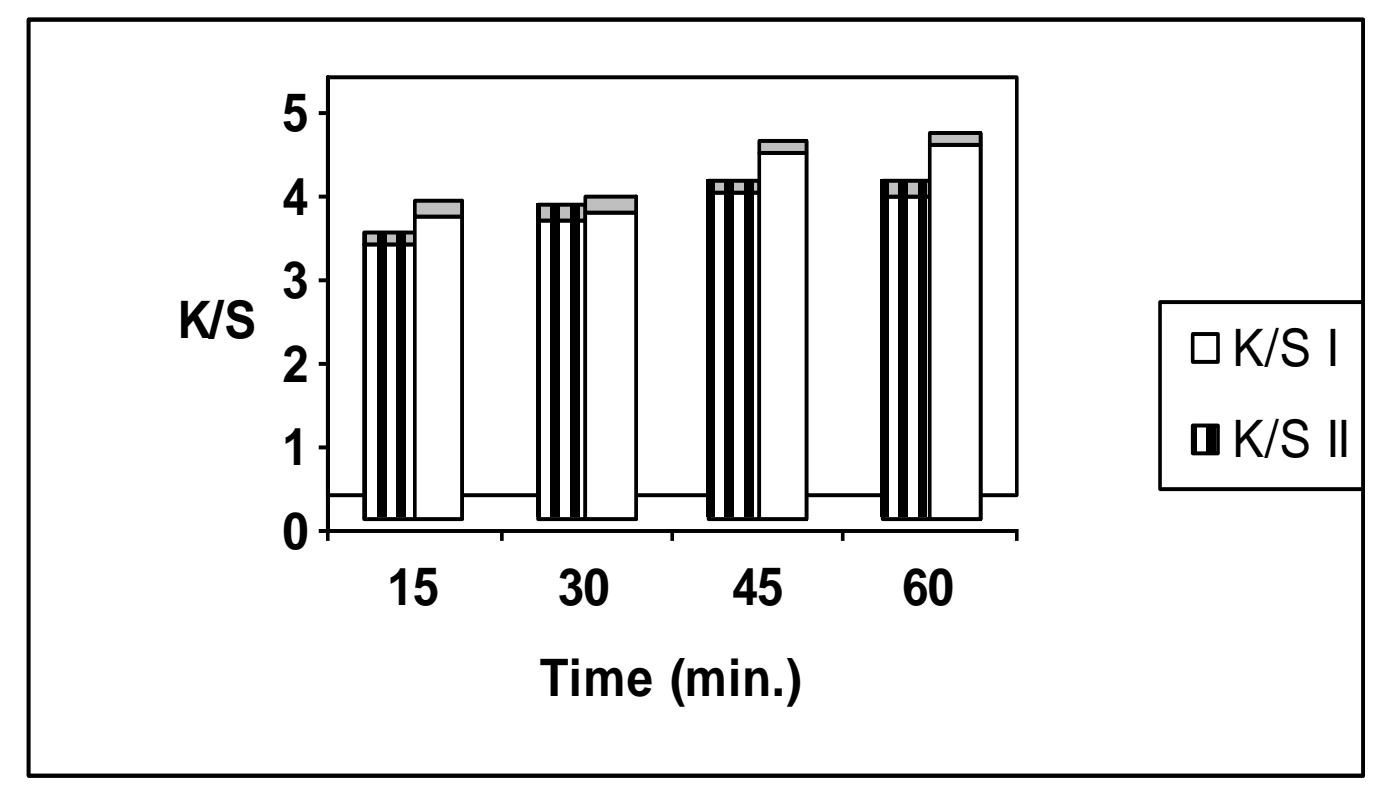

Figure 4. Effect of time on the color strength of Giza 89 cotton fabric (I: conventional processes, II: one- bath processes $\mathrm{NaOH}$ concentration: $(6 \mathrm{~g} / \mathrm{l})$ $\mathrm{Na}_{2} \mathrm{SO}_{4}$ concentration: $(30 \mathrm{~g} / \mathrm{l})$, finishing agent: none).

\section{Effect of $\mathrm{Na}_{2} \mathrm{SO}_{4}$ concentration on color strength (K/S)}

It is clear from figs. 5, and 6 that, the $\mathrm{K} / \mathrm{S}$ value of the treated samples increased according to $\mathrm{Na}_{2} \mathrm{SO}_{4}$ increase until it reached $30 \mathrm{~g} / \mathrm{l}$. when immersed in dye bath, the cellulosic fabrics assume a negative charge and so repel the reactive dye anions. The degree of repulsion between cellulosic fabrics and dye anions depends on the overall negative charge created on the cellulosic fibers and on the negatively charged substitutes of each dye ion. Reactive dye reacts chemically with cellulosic fabrics through the formation of covalent bonds. A particular problem with the application of the reactive dye was the competing reaction with the hydroxide ions in the dye bath to produce a hydrolysed non-reactive form of the dye. Sodium sulphate was added to the dye bath to promote exhaustion of the dye by reducing the electrical potential on the cellulosic fabrics. $\mathrm{Na}_{2} \mathrm{SO}_{4}$ allowing the dye ions to approach the fibers sufficiently closely for nonionic molecular interactions to become operative. Since the effect of $\mathrm{Na}_{2} \mathrm{SO}_{4} 30 \mathrm{~g} / \mathrm{l}$, and $40 \mathrm{~g} / \mathrm{l}$ was similar, it would be more economical to use $30 \mathrm{~g} / \mathrm{l}$ as it still allow the dye ions to approach the fibers sufficiently. The results show that the color strength of Giza 89 was higher than that of Giza 80. 


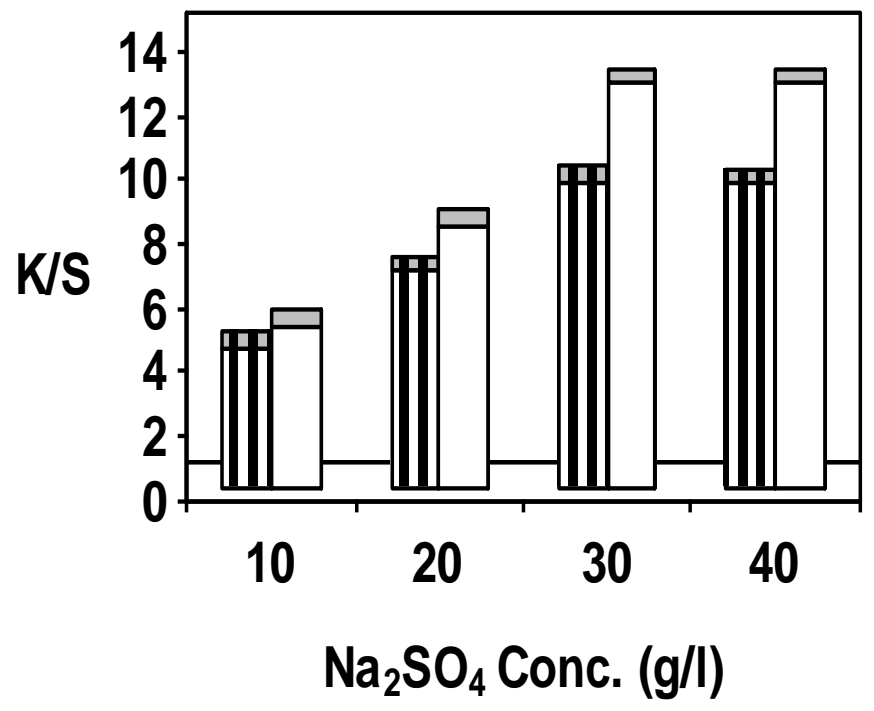

$\square \mathrm{K} / \mathrm{S} \mathrm{I}$

口K/S I

Figure. 5. Effect of $\mathrm{Na2SO} 4$ concentration on the color strength of Giza 89 cotton fabric (I: conventional processes, II: one- bath processes time: 30 minutes $\mathrm{NaOH}$ concentration: $(6 \mathrm{~g} / \mathrm{l})$, finishing agent: none).

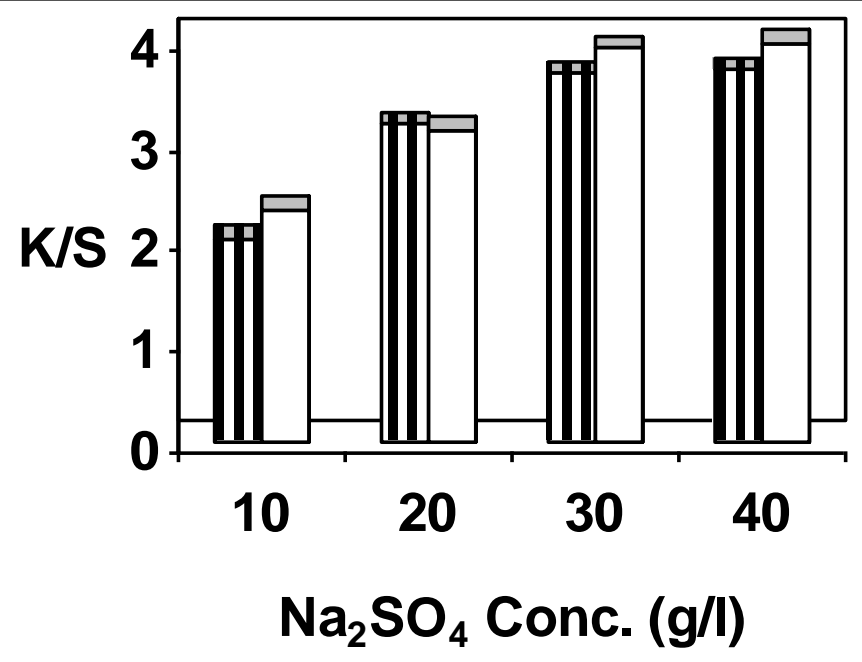

$\square \mathrm{K} / \mathrm{S}$ I

ए K/S II

Figure 6. Effect of $\mathrm{Na} 2 \mathrm{SO} 4$ concentration on the color strength of Giza 80 cotton fabric (I: conventional processes, II: one- bath processes time: 30 minutes $\mathrm{NaOH}$ concentration: $(6 \mathrm{~g} / \mathrm{l})$, finishing agent: none). 


\section{Effect of finishing agent soluble chicken feather (CF) on color strength (K/S)}

The general structural formula of most natural amino acids contain both $(\mathrm{COOH})$ and $(-\mathrm{NH} 2)$ groups, which give them ability to exist either as a cation, anion, or Zwitterion ion depending on $\mathrm{NaOH}$ concentration.

As shown in Fig. 7, at $\mathrm{NaOH}$ hydroxide concentration $6 \mathrm{~g} / \mathrm{l}$, nitrogen atoms on the amino acid adsorb hydrogen ions to create positively charged sites. These sites have a strong attraction to negatively charged dyes, so that the dye uptake increases considerably and the K/S values increased for both Giza 89, and Giza 80 Fabrics.

At $\mathrm{NaOH}$ concentration $8 \mathrm{~g} / \mathrm{l}$, the hydrogen ion concentration was so low that the amount of dye adsorbed decreased extraordinarily. The treated cotton fabric was not able to adsorb much dye through ionic attraction. So, the $\mathrm{K} / \mathrm{S}$ values decrease for the cotton samples.Using $10 \mathrm{~g} / \mathrm{l} \mathrm{NaOH}$, further increase in dye sorption was abserved, due to the hydrolysis of the amino acid by cotton.

As shown in Fig. 8, the $\mathrm{K} / \mathrm{S}$ values of the dyed samples were influenced with the concentration of the soluble chicken feather (CF) as the quantity of finishing (0.5 $\mathrm{g} / \mathrm{l}, 1 \mathrm{~g} / \mathrm{l}, 2 \mathrm{~g} / \mathrm{l}, 3 \mathrm{~g} / \mathrm{l})$, due to increase of total amino acids concentration and a strong attraction to negatively charged dyes occurred, so that the dye uptake increased considerably and the K/S values increased for both varieties Giza 89, and Giza 80.

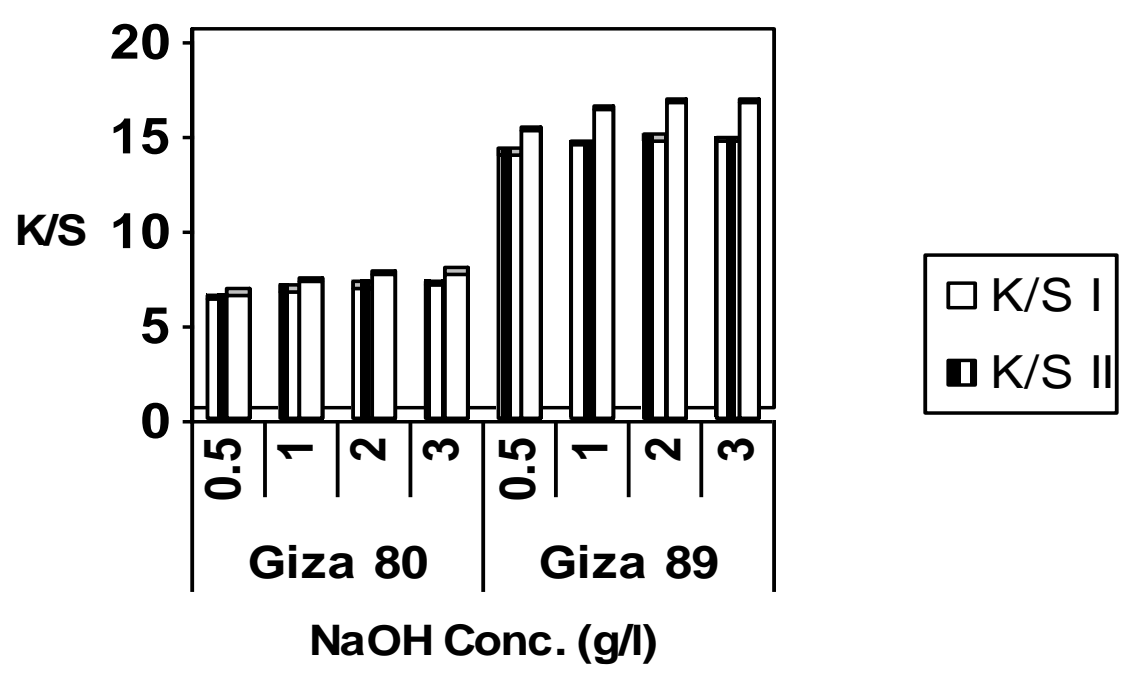

Figure 7. Effect of changing $\mathrm{NaOH}$ concentration on the color strength of Giza 89, and Giza 80 cotton fabrics in presence of $1 \mathrm{~g} / \mathrm{l}$ finishing agent (I: conventional processes, II: one- bath processes time: 30 minutes, $\mathrm{Na}_{2} \mathrm{SO}_{4}$ concentration: $(30 \mathrm{~g} / \mathrm{l}))$. 


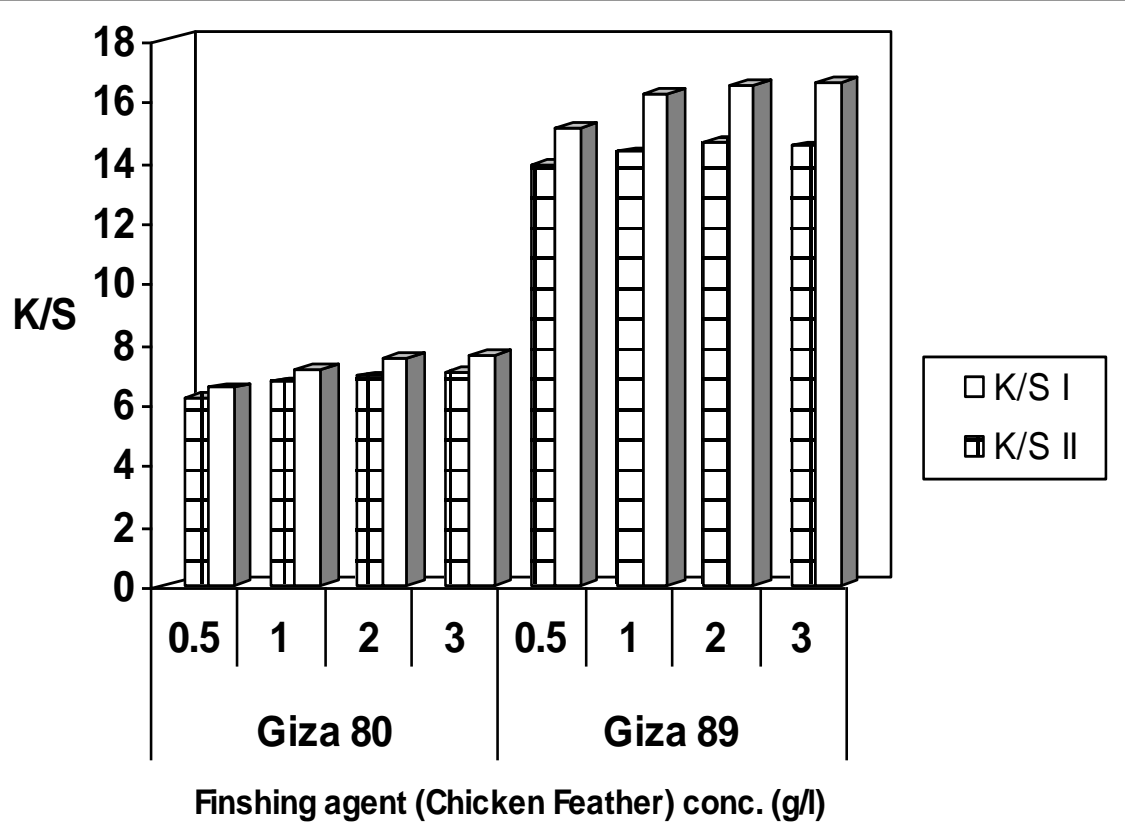

Figure 8. . Effect of changing $\mathrm{NaOH}$ concentration on the color strength of Giza 89, and Giza 80 cotton fabrics (I: conventional processes, II: one- bath processes time: 30 minutes $\mathrm{Na}_{2} \mathrm{SO}_{4}$ concentration: $(30 \mathrm{~g} / \mathrm{l}), \mathrm{NaOH}$ concentration: $(6 \mathrm{~g} / \mathrm{l}))$.

The foreging results reveal that,the optimum conditions for the one-bath process are $\mathrm{NaOH}$ concentration of $(6 \mathrm{~g} / \mathrm{l}), \mathrm{Na}_{2} \mathrm{SO}_{4}$ concentration $(30 \mathrm{~g} / \mathrm{l})$, finishing agent concentration $(2 \mathrm{~g} / \mathrm{l})$, in $95^{\circ} \mathrm{C}$ at 30 minutes.

\section{Tensile strength, elongation and color difference of the one-bath treated \\ fabrics of Giza 89, and Giza 80 cotton fabrics}

As shown in Table 1, at the optimum conditions, the tensile strength $(\mathrm{g} / \mathrm{tex})$, and elongation \% for both Giza 89, and Giza 80 cotton fabrics for one-bath process are little lower than that of the conventional processes due to the higher concentration of $\mathrm{NaOH}$ in the bath. Little difference, is due to the formation of crosslinks between the finishing agent and the cellulose, which hindered the degradation of the fabrics and allows the fabrics to maintain its tensile strength and elongation.

It is clear from Table 1that, the values of $\Delta \mathrm{E}$ for the treated cotton samples in the one-bath treatment are 54.4, and 62.59 for Giza 89, and Giza 80 respectively. This implies that in the one-bath treatment method, wax and other impurities from the raw fabric may be evenly removed during the treatment, even though the treatment time is shorter in this method (as compared with the conventional method). 
Table 1. Tensile strength, elongation and color difference of the one-bath treated fabrics of Giza 89, and Giza 80 cotton fabrics

\begin{tabular}{|c|c|c|c|c|}
\hline \multicolumn{2}{|c|}{ Cotton fabrics } & $\begin{array}{c}\text { Tensile strength } \\
\text { (g/tex) }\end{array}$ & Elongation \% & Color difference $\Delta \mathrm{E}$ \\
\hline \multirow{3}{*}{ Giza 89 } & I & 21.1 & 6.48 & 58.41 \\
\cline { 2 - 5 } & II & 21.00 & 6.45 & 54.40 \\
\hline \multirow{3}{*}{ Giza 80 } & I & 21.0 & 6.48 & 69.70 \\
\cline { 2 - 5 } & II & 21.1 & 6.45 & 62.59 \\
\hline
\end{tabular}

I: conventional processes, II: one- bath processes at optimum condition

\section{Fastness properties of the one-bath treated fabrics of Giza 89, and Giza 80 cotton fabrics}

It is clear from table 2 that the fastness properties of the treated fabrics are rated quite highly. This is because the reactive dye itself has a strong binding power as it binds to the fibers through the covalent bonds. In addition, the presence of sodium sulphate reduced the electrical potential on the cellulosic fabrics, while finishing agent sites have a strong attraction to negatively charged dyes, so that the dye fixation increased considerably. Another approach is that the impurities have been completely removed from the fabric during the one-bath treatment, the dye will not be fixed on the impurities and so, will not affect the fastness.

Table 2. Fastness properties of the one-bath treated fabrics of Giza 89, and Giza 80 cotton fabrics

\begin{tabular}{|c|c|c|c|c|c|c|c|c|c|}
\hline \multicolumn{2}{|c|}{ Cotton fabrics } & \multirow{2}{*}{\multicolumn{2}{|c|}{ Wash }} & \multicolumn{4}{|c|}{ Perspiration } & \multirow{2}{*}{\multicolumn{2}{|c|}{ Crocking }} \\
\hline & & & & \multicolumn{2}{|c|}{ Acidic } & \multicolumn{2}{|c|}{ Alkaline } & & \\
\hline & & St* & Alt** & St* & Alt** & St* & Alt** & wet & dry \\
\hline \multirow[b]{2}{*}{ Giza 89} & I & $4-5$ & $4-5$ & 4 & 4 & 4 & 4 & $3-4$ & 4 \\
\hline & II & $4-5$ & 4-5 & 4 & 4 & 4 & 4 & $3-4$ & 4 \\
\hline \multirow[b]{2}{*}{ Giza 80} & $\mathrm{I}$ & $4-5$ & $4-5$ & 4 & 4 & 4 & 4 & $3-4$ & 4 \\
\hline & II & $4-5$ & $4-5$ & 4 & 4 & 4 & 4 & $3-4$ & 4 \\
\hline
\end{tabular}

I: conventional processes, II: one- bath processes

\section{CONCLUSION}

This investigation aimed to explore the feasibility of integrating the dyeing and its pretreatment (scouring, and bleaching), then finishing for both Giza 89, and Giza 80 Egyptian cotton fabrics in one-bath processes as compared with the conventional processes. The results of the investigation reveal that: 
1. The $K / S$ value of the treated fabrics by the conventional method is slightly better than the cotton fabrics treated by the one-bath method.

2. The $K / S$ value of the treated fabrics increased with the increase in concentration of $\mathrm{NaOH}$ and $\mathrm{Na}_{2} \mathrm{SO}_{4}$, addition of finishing agent and pretreatment time.

3. The tensile strength, elongation, and color difference of the treated fabrics by this method are of the acceptable limits.

4. The addition of chicken feather as a finishing agent $(2 \mathrm{~g} / \mathrm{l})$ increased the $\mathrm{K} / \mathrm{S}$ value and maintain the tensile strength, and elongation from degradation.

5. The wash, perspiration, and crocking properties of the cotton fabrics axeed the acceptable standards.

6. The revival and optimization of old dyeing techniques for industrial use.

7. The combination of certain steps together, thereby shortening the processing steps and consequently conserving energy.

\section{REFERENCES}

1. Gailute, K., V. Valiene and A., Abraitiene. 2004.Environmental Research, Engineering and Management. No.2 (28), P.40- 47.

2. Siriwan, K. 2006. J. Sci. Res. Chula Univ., V. 31, No. 2.

3. Hafiz, A. F., M.H. El-Sisi, M. El- Rafie, M. Helmy and A. Hebeish. 1991. Am. Dyes. Reptr, V. 80, No. 3, p 3734.

4. Yen M. S. and K.S. Huang. 1997. J. S. D. C 113, p. 95-98.

5. Sekar N. 1999. Colourage, May, P. 31.

6. Min. R. R. and S. K. Haung. 1999. J. S. D. C. V. 115 (2) P 69-72.

7. Mortazavi S. M. and A. Ziaie. 2008. Textile Research Journal V. 78 (6) P 497501.

8. Polonca. P. and F. T. Petra. 2007. Color. Technol., V. 124, No. 20, Nov.

9. Subramanian, M., T. Ramachadran, K. Senthil and R. Nithyanandan. 2005. The Indian Textile Journal, Sept. $\mathrm{p}$.

10. Huang K.S. and M. S. Yen. 1997. Am. Dyes Reptr, 84(4), p. 37-47.

11. Khaled, N., S. M. Saleh and A. A. Ramadan. 2006. JTATM, V.5 Issue 2, Sept.P.

12. Huang K. S. 1999. Am. Dyestuff. Rptr., April, p. 59-62. 


\title{
تقنيات جديدة للمعالجات الأولية و الصباغة و التجهيز

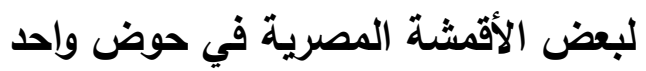

\author{
صلاح منصور صالح' أيمن ناجح عزيز ' \\ ا ـ معهد بحوث القطن -مركز البحوث الزراعية - الجبيزة \\ r r شعبة النسيج - المكز القومي للبحوث - الدقي - الجيزة
}

يعهد هذا البحث إلي دراسة إمكانية إجراء المعالجات الأولية و الصباغة و التجهيز لأقمشة القطن

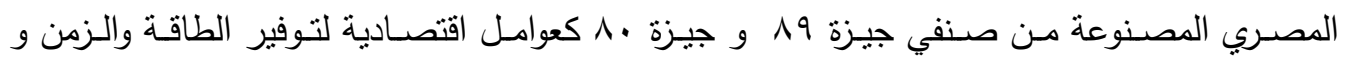

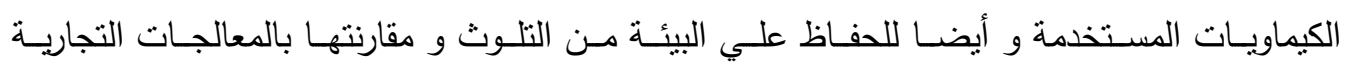
المستخدمة حاليا ( غليان ثم تبييض ثم صباغة ثم تجهيز في أحواض منفصلة). تم في هذا البحث القيام بالدراسات الآتية: ا- دراسـة تأثير نزكيز كل من هيدروكسيد الصوديوم- كبريتات الصوديوم- الزمن و كذلك نركيز

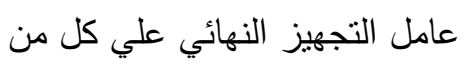

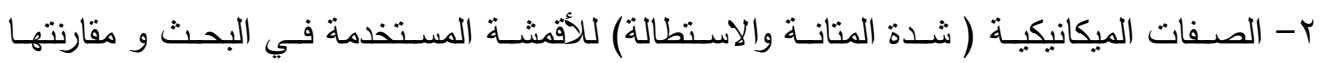
بالطريقة التجارية ب- دراسة قباس الخواص اللونية مثل قيم درجة عمق الصباغة K/S و أيضا درجة اختلاف اللون دE للأقشة المستخدمة في البحث و مقارنتها بالطريقة التجارية

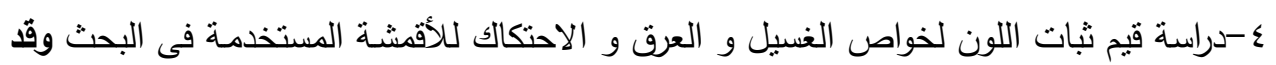

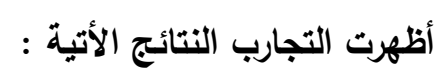

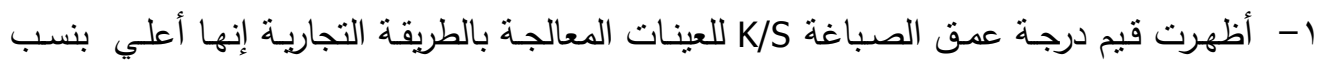

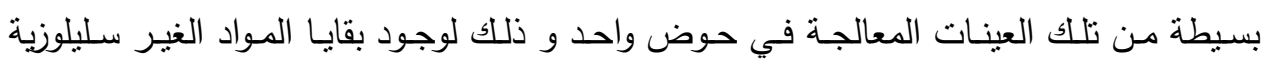

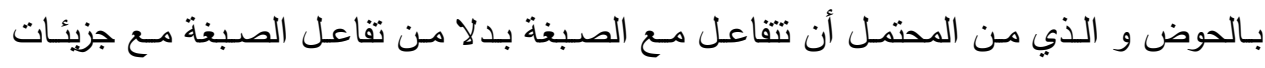
الهيدروكسيل الحرة علي سطح الأقمشة مسببة بعض التناقص في قيم عمق اللون

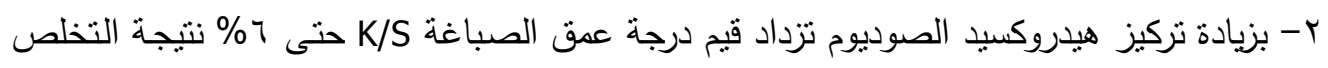

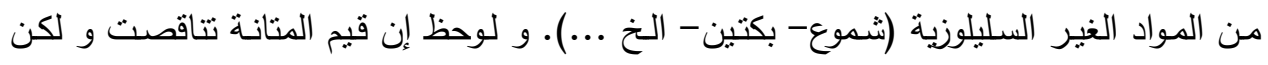
بنسب بسيطة و ذلك نتيجة وجود عامل التجهيز و الذي أدي إلي تكوين روابط عرضية حدت

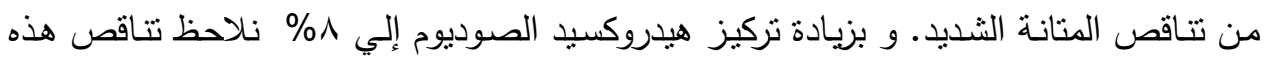

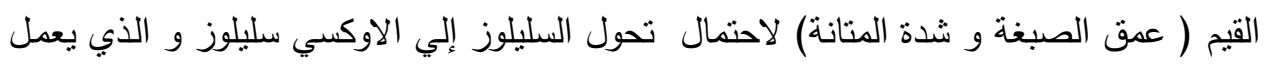

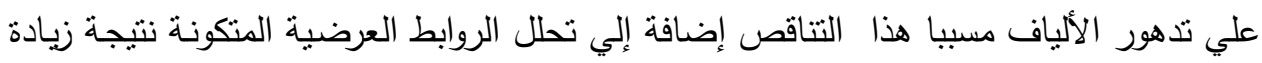

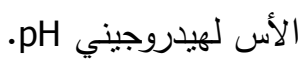


ب- بزيادة تركيز كبريتات الصسوديوم تزداد قيم درجة عمق الصباغة K/S حتى · بَج/ل حيث تعمل

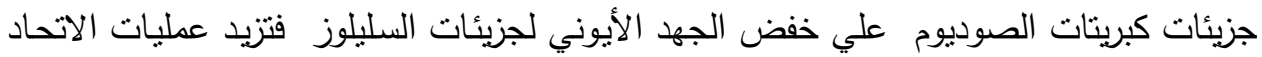
بين جزيئات السليلوز مع الصبغة المستخدمة.

ع - الزمن اللازم لإجراء المعالجات في حوض واحد كانت 0؛ دقيقة و بزيادة الزمن الي •ج دقيقة وجد ان هذه القيم لا تتغير و هي كافية للتخلص من المواد الغير السليلوزية (شموع- بكتين- الخ لخدئ (.... لتسمح للتفاعل التام بين جزيئات السليلوز مع الصبغة. 0- وجد انـه لا يوجد تقريبا اختلاف عند مقارنـة نتائج المعاملات بـالحوض الواحد مـع المعـاملات التقليدية والتي تم الحصول عليها بالنسبة لدرجة اختلاف اللون و ثبات اللون للغيل او العرق

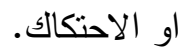

צ- إضافة عامل التجهيز بالإضافة إلي أنه من المخلفات تم الاستفادة منه ( اعادة التدوير) و تحويله

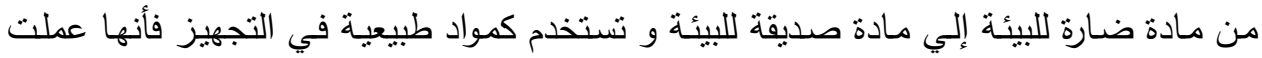
علي زيادة درجة عمق الصبغة و أيضا الحد من نتاقص المتانة كنتيجة لتكوين الروابط العرضية بين جزيئات السليلوز وهذه المادة.

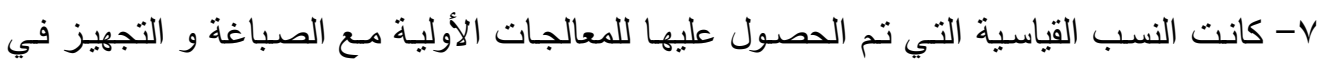
حوض واحد لتعطي نفس النتائج مقارنة بالمعالجات التجارية مـع الأخذ في الاعتبار المميزات التي تم الحصول عليها هي:

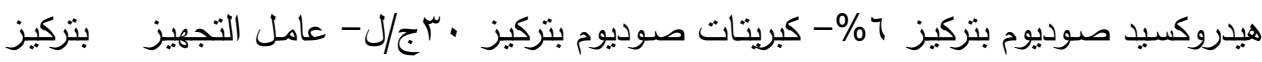

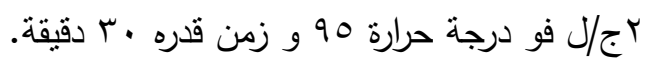

و كنتيجة نهائية لهذا البحث فأنه أمكن استخدام تقنية جديدة للمعاملات الأولية و والصباغة و التجهيز في حوض واحد للأقششة المصرية لصنفي جيزة وم و جيزة ·ـ بهدف العمل علي تطوير

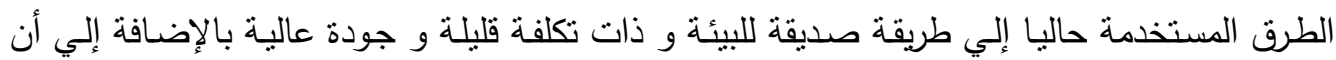

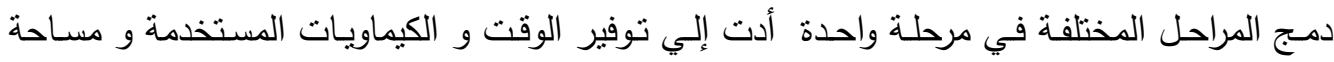
المصنع و تخفيض العمالة مما يؤدي إلي زيادة الأرباح. 